\title{
Sir Thomas Hudson Beare, B.A., B.Sc., LL.D.,
} M.Inst.C.E., M.I.Mech.E.

Sir Thomas Hudson Beare, Regius Professor of Engineering at the University of Edinburgh, died on June I0, 1940.

He was born at Adelaide, South Australia, in I 859, and was educated at Prince Alfred College and the University of Adelaide. After taking first place in the Civil Service examination of South Australia, he obtained an appointment in the Public Works Department, where he was engaged on railway work for three years. After resigning from this post, he completed the degree of B.A., was awarded the Fife (Australia) Scholarship, and proceeded to London, where he studied at University College and obtained the B.Sc. degree of London University.

In I 884, after further practical experience in this country, he was invited to join the staff at University College, London, where he assisted Professor A. B. W. Kennedy in teaching and in private professional work.

His connection with Edinburgh began in 1887 , when he became the first occupant of the Chair of Mechanics and Engineering at the HeriotWatt College where, in two years, he built up a most successful department and designed and equipped the first Engineering Laboratory in Scotland for teaching and research work.

On the resignation of Professor Kennedy, in I 889, Hudson Beare was appointed to the Chair of Mechanical Engineering at University College, London, and was largely responsible for the planning and equipment of the new Engineering Department which was built in 1895 . During this period he was able to carry out a considerable amount of research work, and was awarded the Telford Premium by the Institution of Civil Engineers for a valuable paper on "The Building Stones of Great Britain."

$\mathrm{He}$ was a member of the Committee, of the Institution of Civil Engineers, on Standards of Thermal Efficiency for Steam Engines and of the Marine Engine Trials Committee, of the Institution of Mechanical Engineers.

In I90I, Hudson Beare returned to Edinburgh on his appointment to the Chair of Engineering at the University and at once began the reorganisation of what was then a small and poorly equipped department. In 1905, new laboratories were occupied at High School Yards. Under his influence the Edinburgh School attained a very high status, students 
being attracted to it from all parts of the Empire, and their number increased very rapidly.

The accommodation at High School Yards was taxed to the utmost, and, although the equipment had been recently increased and the laboratories reorganised, Sir Thomas eagerly seized the opportunity for further expansion, and in 1931 the department was moved to the Sanderson Laboratories at King's Buildings.

In 1913, Sir Thomas was elected Dean of the Faculty of Science, which post he held continuously for the period of twenty-eight years, and his expert knowledge and great administrative ability enabled him to render invaluable service to the University.

For many years he was Convener of the Works Committee of the University Court and carried the enormous responsibility of supervising the design and erection of many new departments and of the many alterations required to adapt the older buildings to modern requirements.

Appointed Convener of the Military Education Committee in I904, he continued in that office until his death, and his keen personal interest was largely instrumental in raising the Edinburgh University Contingent of the Officers' Training Corps to its very high state of efficiency. He also represented the University as a member of the City of Edinburgh Territorial and Air Force Association, and for a period was Chairman of that body.

He was Vice-President of the Board of Governors of the Edinburgh and East of Scotland College of Agriculture from 1932, Chairman of the Board of Governors of the Royal (Dick) Veterinary College from I923, and for many years a Governor of the Heriot-Watt College.

In I92 I, he was appointed, by the Secretary of State for Scotland, an Assessor on the Central Miners' Welfare Committee, and served on the Commission until the time of his death.

Knighthood was conferred upon him in 1926 , and ten years later he received the Honorary Degree of LL.D. from the University of Edinburgh.

$\mathrm{He}$ was a member of the Institution of Civil Engineers, a member, and later an Honorary Life Member, of the Institution of Mechanical Engineers, and a member and Vice-President of the Institution of Structural Engineers. He was a Justice of the Peace and Deputy Lieutenant of the County of the City of Edinburgh.

Hudson Beare was a man of outstanding ability and of tremendous energy, and in the midst of his many responsibilities he maintained his keen interest in his profession and in the work of his department. Keeping closely in touch with the latest developments in Engineering, his power as a teacher enabled him to do much for the advancement of Engineering 
Education, and he was happy in being able to carry on this work right up to the end of his life.

His friendly interest in students and in all their activities inspired in them feelings of regard and confidence which were reflected in the close associations they maintained with him throughout their subsequent careers.

He travelled widely and also found recreation in an intensive study of the systematics of the Coleoptera, on which subject he was responsible for numerous publications and was accepted as an authoritative specialist.

Elected a Fellow in I888, he served on the Council from 1907 to 1909 and acted as Vice-President from 1909 to 1915 , and again from 1923 to I926.

J. B. T. 